\title{
Resenhas
}

\section{Universidade e Transformação}

\author{
Rollember, M. (2005). Universidade: Formação \& transformação.
}

São Paulo, SP: Edusp; 264p.

Ao longo dos séculos a Universidade passou a assumir papéis sociais cada vez mais marcantes indo além da produção de conhecimento, da formação profissional e da atividade de extensão. Ao completar seus 70 anos de existência (2004) Universidade de São Paulo promoveu vários eventos e publicações, entre estas últimas situa-se o livro aqui resenhado, cuja apresentação foi escrita pelo próprio organizador. Trata-se de textos com relativa independência, o que flexibiliza o uso da obra, os quais objetivam subsidiar o pensar e o repensar a Universidade, a necessidade de reinventar seus cursos diariamente, seus valores, sua relação com a sociedade.

O livro é composto por seis partes com capítulos sob a responsabilidade de autores diversos. A Parte I tem por título a Tríplice coroa da Universidade: pesquisa, ensino e extensão e é constituída por quatro capítulos. No primeiro deles, Adilson Avansi de Abreu enfoca a relação USP - sociedade tendo por ponto de partida o decreto que criou a Universidade em 1934, no qual a tríplice função básica já estava enunciada. Em seguida, Luiz Nunes de Oliveira explicita claramente que em um trabalho, hoje ninguém "pode dar-se ao luxo de não fazer iniciação científica” (p 27) e que esta vivência precisa ser parte obrigatória dos cursos e que a USP sempre teve liderança nesta área. Sem sólida formação em pesquisa não há como formar bem o profissional nem garantir competência para a atualização. Sonia Terezinha de Souza Penin dá continuidade discutindo justamente o papel da Universidade na formação profissional, aspecto em que passaram a ser mais cobradas no século $X X$, em parte, pelo seu maior envolvimento com a sociedade, contribuindo com a criação cientifica para um mundo mais produtivo, para o engrandecimento do país e para a realização pessoal. A continuidade emerge no texto de Suely Vilela enfocando a pós-graduação e seu papel na transformação do mundo que também está passando por rápidas mudanças. Os pós -graduados são recursos humanos imprescindíveis no mundo moderno. Todavia, no Brasil e países similares, ainda há muito por fazer para a desejável integração desta força, principal componente do desenvolvimento das nações.

A Parte II tem por título Os Papéis da Universidade e é integrada por quatro textos, sendo o primeiro deles é de Juan Diaz Bordenave e trata da formação universitária. Lembra o desequilíbrio na distribuição da verba, de atenção e mesmo de status entre: ensino $(80 \%)$, pesquisa (15\%) e extensão (5\%). Isto torna muitas Universidades em meras "fábricas de diplomas, pesquisando pouco ou nada e não se projetando significativamente à comunidade" (p49). Para assegurar um ensino de qualidade é preciso cuidar da pesquisa e da extensão, pois são processos imprescindíveis à aprendizagem da realidade e da integração. Sem um tratamento integrado da tríade, com alimentação recíproca e eqüitativo não há como fazer uma formação integrada e realista do futuro profissional. Dando prosseguimento ao tema Luiz Carlos de Menezes trata da formação para o trabalho e para a vida em sociedade aspecto básico no mundo de hoje.

Desafios da Universidade: caminhos e possibilidades é o título da Parte III cujo primeiro texto é da autoria de Hélio Mattar e enfoca integração, paixão e valores começando por destacar a enorme 
distância entre as possibilidades e o pouco evoluir das mentalidades. Em seguida, Márcio Pochmann trata da relação educação-trabalho, analisa as necessidades educacionais para o mercado de trabalho. Dando continuidade ao tema, Maria Ruth Amaral de Sampaio e Paulo César Xavier Pereira tratam da premência da Universidade difundir e produzir conhecimento para o trabalho contribuindo para a transformação e o desenvolvimento. É necessário discutir as conseqüências econômicas e políticas desta atuação da Universidade, levando-se em consideração a equidade social e o que é mais importante na formação do cidadão.

A parte seguinte enfoca algumas trajetórias ocorridas na USP e um primeiro capítulo é assinado por Cremilda Medina que relata sua vivência vindo de uma Universidade Federal, para USP e o caldo cultural para pesquisa que encontrou. José Alberto de Souza Freitas expressa o significado da própria USP para os que nela atuam. Sylvia Leser Melo retoma a questão da formação dos jovens destacando a "indissociabilidade das atividades de ensino, pesquisa e extensão" (p.III). Vahan Agopyan tece considerações sobre o ensino de engenharia e a inserção social dos engenheiros com destaque para a formação na USP e aos seus programas vinculados ao social.

O pensar e o fazer universitário do prisma dos que foram reitores da USP compreende a Parte V. É uma série de entrevistas em que enfocaram a trajetória pessoal dos entrevistados com ênfase na sua atuação na USP e suas perspectivas sobre ela e o seu futuro. Os depoimentos são organizados na seguinte ordem: Miguel Reale (1949-1950,1969-1973), Waldyr Munis
Oliva (1978-1982) Antônio Hélio Guerra Vieira (1982-1986), José Goldemberg (1986-1990) Roberto Leal Lobo e Silva Filho (1990-1993), Ruy Laurenti (1993), Flávio Fava de Moraes (1993-1994), Jacques Marcovitch (I997-200I) e Adolpho José Melfi (200l-2005). Todos os depoimentos começam por uma rápida apresentação do depoente e seguem as perguntas e respectivas respostas que são específicas para cada um deles mas permitem compreender suas percepções, atuações e perspectivas sobre a USP.

A última parte do livro recebeu a denominação de Um Convite para o Futuro e é composta por dois textos de Sérgio Muniz Oliva Filho. No primeiro deles trata da Coordenadoria Executiva da cooperação Universitária e Atividades Especiais - Cecae- da USP, criada em 1988, com o objetivo de articular iniciativas e projetos de extensão universitária que foi se expandindo e se transformou em um espaço de formação continuada que abriga vários projetos e programas permanentes. O segundo texto é um breve complemento ao primeiro e apresenta os pontos básicos de um programa de atividade para a Universidade.

Além das partes referidas o leitor encontra: Epílogo - o convite por meio do qual é convidado a participar de várias formas do evoluir da USP e contribuir para que ela seja, de fato "uma Universidade conectada" (p.25l)

São textos de leitura fácil, agradável, uns mais descritivos/informativos, outros que instigam mais o repensar, não apenas o evoluir da USP, mas da própria Universidade brasileira, ou mesmo ir além das fronteiras nacionais. 